Осадча Ю. В., Сахацький Г. І.

УДК 636.52/58:636.083:591.044:591.111

ЕФЕКТИВНІСТЬ ВИРОБНИЦТВА ХАРЧОВИХ ЯЄЦЬ ЗА

ВИКОРИСТАННЯ ДЛЯ УТРИМАННЯ НЕСУЧОК МОНОХРОМНОГО

СВІТЛА $З$ РІЗНОЮ ДОВЖИНОЮ СВІТЛОВОЇ ХВИЛІ

Ю. В. ОСАДЧА, кандидат сільськогосподарських наук, доцент

Національний університет біоресурсів і природокористування Украӥни

Г. І. САХАЦЬКИЙ, кандидат сільськогосподарських наук, доцент

Приазовський держсавний технічний університет

E-mail: seledat@ukr.net, sakhatsky13@ukr.net

https://doi.org/10.31548/dopovidi2021.06.011

Анотація. Досліджено ефективність виробництва харчових яєць за використання для утримання курей-несучок монохромного світла з різною довжиною світлової хвилі. Виявлено, щзо зменшення довжини світлової хвилі від 653 до 632 нм, тобто зміна кольору світла з червоного до помаранчевого, не призводить до значного зниження збереженості курей та маси їх яєць, однак супроводжується зниженням несучості, щуо спричиняє зниження виходу яйцемаси на початкову несучку, у результаті європейський коефічієнт ефективності виробництва яєць знижується на 1,0 од. Зменшення довжини хвилі світла до 603 нм, тобто до жовтого кольору, призводить до істотного зниження збереженості курей $і$ їх несучості за підвищення витрат корму на виробництво 1 кг яйцемаси, що спричиняє зниження європейського коефіцієнту виробництва яєц̧ь на 2,6 од. Подальще зменшення довжини хвилі світла до 458 нм, тобто до блакитного кольору, супроводжується наростаючим зниженням збереженості поголів'я курей та їх несучості за підвищення витрат корму на виробництво 1 кг яйцемаси, щуо в кінцевому підсумку призводить до зниження європейського коефіцієнту ефективності виробництва харчових яєць на 3,8 од.

Ключові слова: кури несучки, несучість, яйцемаса, збереженість, жива маса, довжина світлової хвилі, колір світла

Актуальність. Штучне світло, як чинник довкілля, має вирішальне значення для вивільнення гормонів, які відіграють ключову роль у життєдіяльності, рості, імунітеті та розмноженні птиці [15]. Для курейнесучок світло відіграє важливу роль у розвитку та функціонуванні репродуктивної системи, істотно впливаючи на вік знесення першого яйця, несучість та продуктивність загалом [6,11,13].

Джерелом штучного світла останнього покоління у птахівництві є світлодіодні світильники (LED). Порівнюючи 3 лампами розжарювання та люмінесцентними лампами, світлодіодні мають більший термін служби, специфічний спектр, меншу теплову потужність, вищу енергоефективність та надійність, а 
Осадча Ю. В., Сахацький Г. І.

також менші витрати на обслуговування [16,21,23], тому все частіше використовуються виробничниками [20].

Світлодіоди (LED) - це особливий вид напівпровідникових діодів, які можуть давати монохромне світло. Колір світла визначається довжиною хвилі видимого спектру, а монохромне світло має одну пікову довжину світлової хвилі [24]. Доведено, що довжина хвилі світла впливає на поведінку, добробут та продуктивність птиці $[12,18,22]$. Однак інформація щодо впливу монохромного світла 3 різною довжиною пікової світлової хвилі на фізіологічний стан організму курей досить суперечлива. Тому актуальним $є$ вивчення ефективності виробництва харчових яєць за використання монохромного світла 3 різною довжиною світлової хвилі.

Аналіз останніх досліджень та публікацій. Світло $є$ ефективним чинником контролю фізіологічних та поведінкових процесів, які впливають на несучість курей та якість їх яєць [24]. На відміну від багатьох видів тварин, кури мають здатність бачити довжину світлової хвилі в діапазоні від 380 до 760 нм, а також можуть розрізняти колір світла [17]. У них, крім очей, у трансдукції фотостимуляції беруть участь позасітківкові фоторецептори, розташовані в гіпоталамусі та в інших ділянках мозку [19]. Однак аналіз попередніх досліджень показує, що дані про вплив монохромного світла на несучість курей та якість їх яєць досить суперечливі. Так, за даними одних дослідників [9], використання блакитного світла, порівняно з білим, зеленим та червоним, сприяє підвищенню несучості курей. Блакитний спектр світла також стимулює підвищення концентрації фолікулостимулюючого гормону в крові курей, однак за використання червоного світла підвищується концентрація лютеїнізуючого гормону [14]. Тоді як на думку інших вчених, використання саме червоного спектру світла сприяє підвищенню несучості курей [5,25] та товщини яєчної шкаралупи [7], а блакитного та зеленого - підвищенню маси яєць [5]. C також повідомлення про те, що використання червоного світла спричиняє значне зменшення маси яєць, а якість яєць покращується за використання зеленого світла [4]. Водночас, низкою дослідників показано, що монохромне світло не впливає на несучість курей та якість їх яєць $[2,3,8,19]$, а також не позначається на концентрації гормонів у крові [10].

Мета роботи - дослідити ефективність виробництва харчових яєць за використання монохромного світла 3 різною довжиною світлової хвилі.

Методи. В якості об'єкта досліджень використовували яєчних курей промислового стада «Нy-Line $\mathrm{W}-36 »$. Досліди 3 
Осадча Ю. В., Сахацький Г. І.

експериментальними тваринами проводили відповідно до правил Європейської конвенції про захист хребетних тварин (Офіційний вісник Європейського Союзу L276/33, 2010).

В умовах сучасного комплексу 3 виробництва харчових яєць сформували 4 групи яєчних курей промислового стада «Нy-Line W-36», кожну з яких утримували у окремому пташнику-аналогу за площею та клітковим устаткуванням. Кожен пташник був обладнаний клітковими батареями «Big Dutchman» (Німеччина), що складалися 31176 кліток площею 40544 cм$^{2}(362 \times 112$ см). Відмінності між пташниками стосувалися лише світлодіодних світильників (табл. 1).

\section{1. Схема досліду}

\begin{tabular}{|c|c|c|c|c|}
\hline \multirow{2}{*}{ Характеристика } & \multicolumn{4}{|c|}{ Група курей } \\
\hline & 1 & 2 & 3 & 4 \\
\hline Пікова довжина хвилі, нм & 458 & 603 & 632 & 653 \\
\hline Колір спектру & блакитний & жовтий & помаранчевий & червоний \\
\hline Кількість голів у клітці & \multicolumn{4}{|c|}{101} \\
\hline Кількість голів у групі & \multicolumn{4}{|c|}{118776} \\
\hline Щільність посадки, гол./м² & \multicolumn{4}{|c|}{24,9} \\
\hline Забезпеченість площею, см²/гол & \multicolumn{4}{|c|}{401,4} \\
\hline Площа клітки, см² & \multicolumn{4}{|c|}{40544} \\
\hline Кількість ніпелів у клітці, шт. & \multicolumn{4}{|c|}{12} \\
\hline Фронт годівлі, см & \multicolumn{4}{|c|}{7,8} \\
\hline Площа пташника, м² & \multicolumn{4}{|c|}{2915} \\
\hline
\end{tabular}

Так, курей 1-ї групи утримували 3 використанням світлодіодних світильників із піковою довжиною світлової хвилі 458 нм (блакитний колір спектру), 2-ї групи - 603 нм (жовтий колір спектру), 3-ї групи 632 нм (помаранчевий колір спектру) та 4-ї групи - 653 нм (червоний колір спектру).

Упродовж досліду курей забезпечували питною водою, повнораціонними комбікормами однакового складу та утримували згідно 3 вимогами (ВНТП-АПК04.05.). Щодня, упродовж 44 тижнів продуктивного періоду, визначали кількість яєць, знесених несучками кожної групи та інтенсивність їх несучості. Здійснювали також щодня облік кількості курей, що вибули (через падіж i вибракування) та визначали збереженість поголів'я. Раз на тиждень вимірювали масу яєць та живу масу несучок із певних маркованих кліток за вибіркою, яка

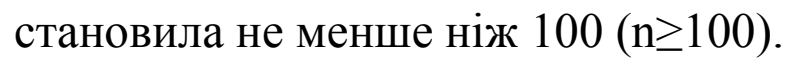

Європейський коефіцієнт ефективності виробництва яєць визначали за формулою [1]:

$$
\text { Єке }=(1,4 \text { х M) - }(0,35 \text { х K) }
$$

де: Єке - європейський коефіцієнт ефективності, од.; 1,4 і 
Осадча Ю. В., Сахацький Г. І.

0,35 - константні значення; $\mathrm{M}$ - яєчна маса (яйцемаса), кг/гол.; К - витрати корму на виробництво 1 кг яєчної маси, кг.

Отримані цифрові результати опрацьовували методами варіаційної статистики. Достовірність відмінностей між середніми величинами визначали за t-критерієм Ст'юдента, різниці вважали достовірними за $\mathrm{p}<0,05$.

Результати. Для визначення ефективності виробництва яєць під час утримання курей за різного кольору світла проведена оцінка їх продуктивності упродовж першого циклу використання, тобто за 62 тижні життя (табл. 2). Збереженість поголів'я у всіх групах була нижчою рівня $(96,4 \%)$, рекомендованого розробником кросу «Нy-Line W-36». Найбільша різниця - 14,0 \%, 3 рекомендованим рівнем збереженості спостерігалась у курей 1-ї групи, тоді як кури 2-ї групи не досягали нормативу на 9,8 \%, 3-ї - на 3,8 \%, а 4$\ddot{1}$ - на 3,1 \%. Водночас, збереженість поголів'я у курей 1-ї групи, яких утримували за блакитного світла, була нижчою на 4,2 \% $(\mathrm{p}<0,001)$ у порівнянні 3 2-ю групою та відповідно на 10,2 \% $(\mathrm{p}<0,001)$ і 10,9 $\%(\mathrm{p}<0,001)$ у порівнянні з 3-ю та 4-ю групами. У курей 2-ї групи, яких утримували за жовтого світла, збереженість була нижчою на 6,0 \% $(\mathrm{p}<0,001)$ та 6,7\% $\%(\mathrm{p}<0,001)$ порівняно з 3-ю та 4-ю групами відповідно. Кури 3-ї групи, яких утримували за жовтого світла, мали нижчу збереженість поголів'я на $0,7 \%(\mathrm{p}<0,001)$ порівняно з 4-ю групою, в якій використовували червоне світло.

За масою тіла курей нормативних показників (1,54-1,58 кг) було досягнуто несучками 2-4-ї груп. Найнижча маса тіла 3 відхиленням від нормативних показників на 0,2% виявлена у курей 1-ї групи, яких утримували за блакитного світла. Вони поступалися за живою масою 2-й групі на 2,3\% $(\mathrm{p}<0,001), 2$-й - на 3,3\% $\%(\mathrm{p}<0,001)$ та 3 -й - на 4,0 \% $(\mathrm{p}<0,001)$. Водночас, несучки 2-ї групи, яких утримували за жовтого світла, мали нижчу масу тіла на $1,0 \%(\mathrm{p}<0,001)$ та $1,7 \%(\mathrm{p}<0,001)$ у порівнянні 3 3-ю та 4-ю групами відповідно. У свою чергу, кури 3-ї групи, яких утримували за помаранчевого світла, мали нижчу масу тіла на $0,6 \% \quad(p<0,001)$ у порівнянні з 4-ю групою, у якій курей утримували за червоного світла.

Несучість на початкову несучку, згідно нормативних вимог у 62 тижні - 262,2-268,7 шт., а на середню - 267,0-273,6 шт. Фактично ж, на початкову несучку, несучість жодної з груп не досягла необхідного рівня. За цього спостерігалось зниження несучості із зменшенням довжини хвилі світла. Зокрема, несучість на початкову несучку була найнижчою у курей 1-ї групи, яких утримували за блакитного світла, 3 відхиленням від нормативу на 16,5 \%. Водночас, несучки 1-ї групи мали 
Осадча Ю. В., Сахацький Г. І.

нижчу несучість на початкову несучку на 5,6 \% $(\mathrm{p}<0,001)$ порівняно з 2-ю групою та на 11,8 \% $(\mathrm{p}<0,001)$ та $15,3 \%(\mathrm{p}<0,001)$ порівняно 3 3-ю і 4ю групами відповідно. Разом 3 тим, несучість курей 2-ї групи, яких утримували за жовтого світла, не досягала нормативу на 11,6 \% та була нижчою на 6,6 \% $(\mathrm{p}<0,001)$ та 10,3\% $(\mathrm{p}<0,001)$ порівняно 3 3-ю і 4-ю групами відповідно. А у курей 3-ї групи, яких утримували за помаранчевого світла, несучість не досягала нормативної на 5,3 \% та була нижчою на 2,9 \% (p<0,001) порівняно 3 4-ю групою. Кури 4-ї групи, яких утримували за червоного світла, характеризувалися найвищою несучістю на середню несучку 3 найменшим відхиленням від нормативу $-1,4 \%$.

\section{2. Обсяги виробництва ясць під час утримання курей за різної довжини світлової хвилі}

\begin{tabular}{|c|c|c|c|c|}
\hline \multirow{2}{*}{ Показники } & \multicolumn{4}{|c|}{ Група несучок } \\
\hline & 1 & 2 & 3 & 4 \\
\hline $\begin{array}{l}\text { Початкове поголів'я несучок в } \\
\text { групі, гол }\end{array}$ & 475104 & 475104 & 475104 & 475104 \\
\hline Збереженість поголів'я, \% & $82,4 \pm 0,11$ & $86,6 \pm 0,10^{* * *}$ & $92,6 \pm 0,08^{* * * 000}$ & $93,3 \pm 0,07^{* * * \circ}$ \\
\hline $\begin{array}{l}\text { Поголів'я несучок } \\
\text { у віці } 62 \text { тиж., гол }\end{array}$ & 391486 & 411440 & 439946 & 443272 \\
\hline $\begin{array}{l}\text { Падіж, } \\
\text { вибракування, гол. }\end{array}$ & 83618 & 63664 & 35158 & 31832 \\
\hline Маса тіла, $г$ & $1506 \pm 0,07$ & $1542 \pm 0,05^{* * *}$ & $1558 \pm 0,12^{* * * 000}$ & $1568 \pm 0,09^{* * * \circ}$ \\
\hline $\begin{array}{l}\text { Несучість на початкову } \\
\text { несучку, шт. }\end{array}$ & $218,9 \pm 0,12$ & $231,8 \pm 0,18^{* * *}$ & $248,3 \pm 0,09^{* * * * 00}$ & $258,4 \pm 0,08^{* * * 000 ! "}$ \\
\hline $\begin{array}{l}\text { Несучість на середню } \\
\text { несучку, шт. }\end{array}$ & $265,7 \pm 0,08$ & $267,7 \pm 0,05^{* * *}$ & $268,1 \pm 0,11^{* * * 000}$ & $277,0 \pm 0,09^{* * * 0001}$ \\
\hline $\begin{array}{l}\text { Отримано яєць } \\
\text { у 62-тиж. віці, шт. }\end{array}$ & 104000266 & 110129107 & 117968323 & 122766874 \\
\hline Маса яєць, г & $63,5 \pm 0,04$ & $63,8 \pm 0,08^{* * *}$ & $64,2 \pm 0,02^{* * * 000}$ & $64,1 \pm 0,03^{* * * 0}$ \\
\hline $\begin{array}{l}\text { Отримано яйцемаси, всього, } \\
\text { кг } \\
\text { - на початкову несучку, кг }\end{array}$ & $\begin{array}{c}6572817 \\
13,8\end{array}$ & $\begin{array}{c}6938134 \\
14,6\end{array}$ & $\begin{array}{c}7443801 \\
15,7\end{array}$ & $\begin{array}{c}7771143 \\
16,4\end{array}$ \\
\hline $\begin{array}{l}\text { Отримано } з 1 \text { м² пташнику: } \\
\text { - яєць, шт. } \\
\text { - яйцемаси, кг }\end{array}$ & $\begin{array}{r}35678 \\
2254,8\end{array}$ & $\begin{array}{l}37780 \\
2380,1 \\
\end{array}$ & $\begin{array}{r}40469 \\
2553,6 \\
\end{array}$ & $\begin{array}{l}42116 \\
2665,9 \\
\end{array}$ \\
\hline Витрати корму, г/гол/добу & $107,4 \pm 0,08$ & $109,6 \pm 0,12^{* * *}$ & $110,4 \pm 0,10^{* * * 000}$ & $110,3 \pm 0,11^{* * * \circ}$ \\
\hline $\begin{array}{l}\text { Затрати корму, } \\
\text { всього, кг } \\
\text { - на } 1 \text { кг яйцемаси }\end{array}$ & $\begin{array}{c}16652585 \\
2,53\end{array}$ & $\begin{array}{c}16813550 \\
2,42\end{array}$ & $\begin{array}{c}17150114 \\
2,30\end{array}$ & $\begin{array}{c}17179381 \\
2,21\end{array}$ \\
\hline $\begin{array}{l}\text { Європейський коефіцієнт } \\
\text { ефективності, од. }\end{array}$ & $18,4 \pm 0,06$ & $19,6 \pm 0,06^{* * *}$ & $21,2 \pm 0,06^{* * * 000}$ & $22,2 \pm 0,06^{* * * 0000+1}$ \\
\hline
\end{tabular}

Примітки: ${ }^{*} \mathrm{p}<0,05,{ }^{* *} \mathrm{p}<0,01, * * * \mathrm{p}<0,001-$ порівняно 3 першою групою; ${ }^{\circ} \mathrm{p}<0,05 ;{ }^{\circ} \mathrm{p}<0,001-$ порівняно з другою групою; 'p<0,001 - порівняно з третьою групою. 
Осадча Ю. В., Сахацький Г. І.

Водночас, за несучістю на середню несучку нормативний рівень досягнутий 2-ю та 3-ю групами, а 4-ю групою - навіть перевищений. Так, найнижча несучість на середню несучку спостерігалась у курей 1-ї групи, яких утримували за блакитного світла, з відхиленням від нормативу на 0,5 \% та, водночас, була нижчою на $0,7 \quad \% \quad(\mathrm{p}<0,001)$ у порівнянні 3 2-ю групою та відповідно на $0,9 \%(\mathrm{p}<0,001)$ і 4,1\% $(\mathrm{p}<0,001)$ у порівнянні 3 3-ю та 4-ю групами. Водночас, кури 2-ї групи, яких утримували за жовтого світла, мали нижчу несучість на $0,1 \%$ $(\mathrm{p}<0,001)$ i 3,4\% $\%(\mathrm{p}<0,001)$ порівняно з 3-ю і 4-ю групами відповідно, а кури 3-ї групи - на 3,2 \% $\quad(\mathrm{p}<0,001)$ порівняно 3 4-ю групою, в якій використовували червоне світло.

Маса яєць несучок кросу «НуLine W-36» у 62-тижневому має становити 63,4 г/шт., а споживання корму - 96-102 г/добу на 1 голову. Як видно 3 дослідних даних (табл. 2), маса яєць курей усіх груп досягала нормативу, а споживання корму перевищувало його. Зокрема, у курей 1-ї групи, маса яєць була нижчою на $0,5 \%(\mathrm{p}<0,001)$ у порівнянні 32 -ю групою та відповідно на 1,1 \% $(\mathrm{p}<0,001) \quad$ та $0,9 \quad \% \quad(\mathrm{p}<0,001) \quad$ у порівнянні 3 3-ю та 4-ю групами. Maca яєць курей 2-ї групи, яких утримували за жовтого світла, була нижчою на 0,6 \% $(\mathrm{p}<0,001)$ порівняно 3 3-ю групою та на $0,5 \%(\mathrm{p}<0,05)$ порівняно з 4-ю групою. У курей 3-ї та 4-ї груп, яких утримували за помаранчевого та червоного світла, відмінності за масою яєць складали лише 0,1 г i статистично не підтвердились.

Що стосується витрат корму, то нормативний рівень був перевищений несучками всіх груп, за цього простежувався чіткий вплив зменшення довжини хвилі світла. Найнижче споживання корму спостерігалось у несучок 1-ї групи, яких утримували за блакитного світла, з перевищенням нормативу на 5,3 \%. Водночас, кури 1-ї групи споживали менше корму на 2,0 \% $(\mathrm{p}<0,001)$ у порівнянні 32 -ю групою та відповідно на 2,7 \% $(\mathrm{p}<0,001)$ та $2,6 \%(p<0,001)$ у порівнянні з 3-ю та 4-ю групами. Кури 2-ї групи, яких утримували за жовтого світла, характеризувались нижчим споживанням корму на $0,7 \%$ $(\mathrm{p}<0,001)$ та $0,6 \%(\mathrm{p}<0,001)$ порівняно 3 3-ю та 4-ю групами відповідно. У курей 3-ї та 4-ї груп, яких утримували, відповідно, за помаранчевого та червоного світла, споживання корму різнилося лише на 0,1 г без статистичного підтвердження.

Отже, для визначення ефективності виробництва харчових яєць залежно від довжини хвилі світла в 4 пташники-аналоги за площею i конструкцією було посаджено однакове поголів'я несучок (табл. 2). Однак, до 62тижневого віку в 1-й групі, в якій курей утримували за блакитного 
Осадча Ю. В., Сахацький Г. І.

світла, вибула найбільша кількість несучок через нижчу збереженість поголів'я $(82,4$ \% порівняно 3 86,693,3 \% у інших групах). Всього в 1-й групі пало або вибракувано 83618 несучок, тобто в 1,3 рази більше, ніж у 2-й (на 19954 гол.) та в 2,4 і 2,6 разів, ніж у 3-й (на 48460 гол) та 4-й (на 51786 гол) групах, що пов'язано із застосуванням світла 3 різною довжиною хвилі, тобто різного кольору. Це спричинило зменшення валового виробництва яєць на 6,1 млн. шт., яєчної маси - на 365,3 т. і іï виходу на початкову несучку - на 0,8 кг у порівнянні 3 2-ю групою та зменшення на 14,0 млн. шт. і 18,8 млн. шт. валового виробництва яєць, на 871,0 т. і 1198,3 т. яєчної маси і їі виходу на початкову несучку - на 1,9 кг і 2,6 кг порівняно 3 3-ю та 4-ю групами відповідно. Також менше отримано 31 м $^{2}$ пташника яєць - на 2,1 тис. шт. і яєчної маси - на 125,3 кг у порівнянні з 2-ю групою та на 4,8 тис. шт. і 6,4 тис. шт. і яєчної маси на 298,8 кг і 588,9 кг, ніж у 3-й та 4-й групах відповідно, за вищих витрат корму на виробництво 1 кг яєчної маси на $0,11,0,23$ та 0,32 кг. Тому i коефіцієнт ефективності виробництва харчових яєць в 1-й групі виявився нижчим ніж у 2-й групі на 1,2 од $(\mathrm{p}<0,001), 3$-й групі - на 2,8 од $(\mathrm{p}<0,001)$ та 4-й групі на 3,8 од $(\mathrm{p}<0,001)$.

У 2-й групі, у якій курей утримували за жовтого світла, пало або було вибракувано 63664 несучок, тобто в 1,8 рази більше, ніж у 3-й (на 28506 гол.) та в 2,0 рази, ніж у 4-й (на 31832 гол) групі. За цього відзначено нижче валове виробництво яєць на 7,8 млн. шт. та яєчної маси - на 505,7 т порівняно 3 3-ю групою, на 12,6 млн. шт. та 833,0 т- порівняно з 4-ю групою. Знижувався також i вихід яйцемаси на початкову несучку - на 1,1 кг порівняно 3 3-ю та на 1,8 кг порівняно з 4-ю групою. Менше було

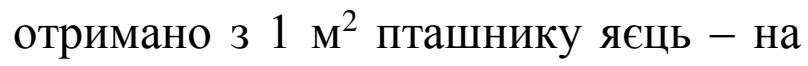
2,7 тис. шт. та яйцемаси - на 173,5 кг у порівнянні з 3-ю групою, на 4,3 тис. шт. та 285,8 кг - порівняно 3 4-ю групою, за вищих витрат корму на виробництво 1 кг яйцемаси на 0,12 кг порівняно з 3-ю групою та на 0,21 кг порівняно 3 4-ю групою. Це призвело до зниження європейського коефіцієнту виробництва яєць на 1,6 од $(\mathrm{p}<0,001)$ та 2,6 од. $(\mathrm{p}<0,001)$ порівняно 3 3-ю та 4-ю групами відповідно.

Водночас, у 3-й групі, у якій курей утримували за помаранчевого світла, пало або було вибракувано 35158 несучок, тобто в 1,1 рази більше, ніж у 4-й (на 3326 гол.) групі. Це спричинило зменшення валового виробництва яєць на 4,5 млн. шт., яєчної маси - на 327,3 т. і їі виходу на початкову несучку - на 0,7 кг. Також менше отримано $31 \mathrm{~m}^{2}$ пташника яєць - на 1,6 тис. шт. і яєчної маси - на 112,3 кг, ніж у 4-й групі, в якій курей утримували за червоного світла, за вищих витрат корму на виробництво 1 кг яєчної маси на 0,09 кг. Тому i 
Осадча Ю. В., Сахацький Г. І.

коефіцієнт ефективності виробництва харчових яєць в 3-й групі виявився нижчим ніж у 4-й групі на 1,0 од $(\mathrm{p}<0,001)$.

Таким чином, зменшення довжини хвилі світла за утримання несучок в 12-ярусних кліткових батареях класичної конструкції від 653 до 632 нм не призводить до значного зниження їх збереженості та маси яєць, однак супроводжується зниженням несучості на початкову та середню несучку.

Це супроводжується зниженням виходу яйцемаси на початкову несучку та витрат корму на 1 кг яйцемаси, у результаті європейський коефіцієнт ефективності виробництва яєць знижується на 1,0 од. Однак, зменшення довжини хвилі світла до 603 нм, тобто до жовтого кольору, вже призводить до істотного зниження збереженості поголів'я i несучості на початкову та середню несучку за зниження загальних витрат корму, однак їх підвищення на виробництво 1 кг яйцемаси, що спричиняє зниження європейського коефіцієнту виробництва яєць на 2,6 од. Подальше зменшення довжини хвилі світла до 458 нм, тобто до блакитного кольору, супроводжується наростаючим істотним зниженням збереженості поголів'я і несучості на початкову та середню несучку за зниження загальних витрат корму, однак їх підвищення на виробництво 1 кг яйцемаси, що в кінцевому підсумку призводить до Зниження європейського коефіцієнту ефективності виробництва харчових яєць на 3,8 од.

Висновки. 1. За утримання курей-несучок сучасних білояєчних кросів у 12-ярусних кліткових батареях класичних конструкцій доцільно застосовувати освітлення із довжиною пікової хвилі 653 нм, тобто iз світлом червоного кольору. Це дає можливість за 44-тижневий період яйцекладки отримувати додатково 4,8-18,8 млн. яєць 3 кожного пташнику (0,4-1,6 тис. шт. 31 м² його площі) за вищого рівня європейського коефіцієнту ефективності їх виробництва на 1,0-3,8 од.

2. Зменшення пікової довжини хвилі від 653 до 632 нм, яке проявлялось зміною світла 3 червоного до помаранчевого, супроводжувалось зниженням збереженості поголів'я на 0,7 \% (3,8 \% $<$ норми), маси тіла - на 0,6 \% в межах фізіологічної норми, несучості на початкову несучку - на 2,9 \% (5,3 \% < норми), що спричинило зменшення валового виходу яєць на 4,5 млн. шт. та яйцемаси - на 3273 т 3 кожного пташнику, у тому числі на 1,6 тис. шт. та 112,3 кг $3 \quad 1 \quad$ м $^{2}$ його площі, із зниженням рівня європейського коефіцієнту ефективності виробництва яєць на 1,0 од.

3. Зменшення пікової довжини хвилі до 603 нм, тобто зміна кольору світла з червоно та помаранчевого на жовте, супроводжувалось зниженням 
Осадча Ю. В., Сахацький Г. I.

збереженості поголів'я на 6,0-6,7 \% (9,8 \% < норми), маси тіла - на 1,01,7 \% в межах фізіологічної норми, несучості на початкову несучку - на 6,6-10,3\% (11,6\% < норми) та витрат корму - на 0,6-0,7 \% (7,5\% > норми), що зумовило зменшення валового виходу яєць на 7,8-12,6 млн. шт. та яйцемаси - на 505,7-833,0 т 3 кожного пташнику, у тому числі на 2,7-4,3 тис. шт. та 173,5-285,8 кг $31 \mathrm{M}^{2}$ його площі, iз зниженням рівня європейського коефіцієнту ефективності виробництва яєць на 1,6-2,6 од.

4. Зменшення пікової довжини хвилі до 458 нм, тобто зміна кольору світла $з$ червоного, помаранчевого та

\section{Список використаних джерел}

1. Кавтарашвили А. Ш. Определение эффективности производства птицеводческой продукции экспрессметодами. Економика. 2013. № 2(123). С. $6-$ 9.

2. Borille R., Garcia R.G., Naas I.A., Caldara R.F., Santana M.R. Monochromatic lightemitting diode (LED) source in layers hens during the second production cycle. Revista Brasileira de Engenharia Agrícola $e$ Ambiental. 2015. Vol. 19(9). P. 877-881. doi:10.1590/1807-1929/agriambi.v19n9p877881

3. Borille R., Garcia R.G., Royer A.F.B., Santana M.R., Colet S., Naas I.A., Caldara F.R., Almeida Paz I.C.L., Rosa E.S., Castilho V.A.R. The use of light-emitting diodes (LED) in commercial layer production. Brazilian Journal of Poultry Science. 2013. Vol. 15(2). P. 135140. doi:10.1590/S1516-635X2013000200009

4. Er D., Wang Z., Cao J., Chen Y. Effect of monochromatic light on the egg quality of laying hens. Journal of Applied Poultry Research. 2007. Vol. 16(4). P. 605-612. doi:10.3382/japr.2006-00096 жовтого

на

блакитне,

супроводжується

зниженням

збереженості поголів'я на 4,2-10,9\% (14,0 \% < норми), маси тіла - на 2,3$4,0 \%$ (0,2 \% < норми), несучості на початкову несучку - на 5,6-15,3 \% (16,5 \% < норми) та витрат корму - на $2,0-2,7 \%$ (5,3 \% > норми), що спричинило зменшення валового виходу яєць на 6,1-18,8 млн. шт. та яйцемаси - на 365,3-1198,3 т 3 кожного пташнику, у тому числі на 2,1-6,4 тис. шт. та 125,3-288,9 кг 31 $\mathrm{M}^{2}$ його площі, із зниженням рівня європейського

коефіцієнту ефективності виробництва яєць на 1,2-3,8 од.

5. Hassan M.R., Sultana S., Choe H.S., Ryu K.S. Effect of monochromatic and combined light colour on performance, blood parameters, ovarian morphology and reproductive hormones in laying hens. Italian Journal of Animal Science. 2013. Vol. 12(3). P. 359-364. doi:10.4081/ijas.2013.e56

6. Huber-Eicher B., Suter A., SpringStähli P. Effects of colored light-emitting diode illumination on behavior and performance of laying hens. Poultry science. 2013. Vol. 92. P. 869-873. doi:10.3382/ps.2012-02679

7. Kim M.J., Choi H.C., Suh O.S. A study of different sources and wavelengths of light on laying egg characteristics in laying hens. Korean Journal of Poultry Science. 2010. Vol. $37 . \quad P . \quad 383-388$. doi:10.5536/kjps.2010.37.4.383

8. Lewis P.D., Caston L., Leeson S. Green light during rearing does not significantly affect the performance of egg-type pullets in the laying phase. Poultry Science. 2007. Vol. 86. P. 739-743. doi:10.1093/ps/86.4.739

9. Li G., Li B., Zhao Y., Shi Z., Liu Y., Zheng W. Layer pullet preferences for light colors of light-emitting diodes. Animal. 2019. 
Осадча Ю. В., Сахацький Г. I.

Vol. 13(6). P. 1245-1251. doi: $10.1017 / \mathrm{S} 1751731118002537$

10. Li D.Y., Wu N., Tu J.B., Hu Y.D., Yang M.Y., Yin H.D., Chen B.L., Xu H.L., Yao Y.F., Zhu Q. Expression patterns of melatonin receptors in chicken ovarian follicles affected by monochromatic light. Genetics and Molecular Research. 2015. Vol. 14 (3). P. 10072-10080. doi:10.4238/2015.August.21.14

11. Li X., Zheng Z., Pan J., Jiang D., Tian Y., Fang L., Huang Y. Impacts of colored lightemitting diode illumination on the growth performance and fecal microbiota in goose. Poultry science. 2020. Vol. 99(4). P. 18051812. doi:10.1016/j.psj.2019.12.034

12. Manser C. E. Effects of lighting on the welfare of domesticpoultry: a review. Animal Welfare. 1996. Vol. 5. P. 341-360.

13. Min J.K., Hossan M.S., Nazma A., Jae C.N., Han T.B., Hwan K.K., Dong W.K., Hyun S.C., Hee C.C., Ok S.S. Effect of monochromatic light on sexual maturity, production performance and egg quality of laying hens. Avian Biology Research. 2012. $\begin{array}{llll}\text { Vol. } & 5 . & \text { P. }\end{array}$ doi:10.3184/175815512X13350270679453

14. Mudhar A.S., Tabeekh A. The effect of color light and stocking density on some enzymes and hormones of broilers and layers. Mirror of Research in Veterinary Sciences and Animals. 2016. Vol. 5(1). P. 25-37. doi:10.5923/j.zoology.20160602.02

15. Patel S.J., Patel A.S., Patel M.D., Patel J.H. Significance of light in poultry production: a review. Advancements in Life Sciences. 2016. № 5. P.1154-1160.

16. Prayitno D.S., Phillips C.J.C., Omed $\mathrm{H}$. The effects of color of lighting on the behavior and production of meat chickens. Poultry science. 1997. Vol. 76. P. 452-457. doi:10.1093/ps/76.3.452

17. Prescott N.B., Wathes C.M. Spectral sensitivity of domestic fowl (Gallus $g$. domesticus). British Poultry Science. 1999. Vol. $40 . \quad$ P. 332-339. doi:10.1080/00071669987412

18. Rozenboim I., Biran I., Uni Z., Robinzon B., Halevy O. The effect of monochromatic light on broiler growth and development. Poultry science. 1999. Vol. 78. P. 135-138. doi:10.1093/ps/78.1.135
19. Rozenboim I., Zilberman E., Gvaryahu G. New monochromatic light source for laying hens. Poultry Science. 1999. Vol. 77. P. 1695-1698. doi:10.1093/ps/77.11.1695

20. Shi H., Li B., Tong Q., Zheng W., Zeng D., Feng G. Effects of LED Light Color and Intensity on Feather Pecking and Fear Responses of Layer Breeders in Natural Mating Colony Cages. Animals : an open access journal from MDPI. 2019. Vol. 9(10). P. 814. doi:10.3390/ani9100814

21. Sultana S., Hassan M.R., Choe H.S., Kang M.I., Ryu K.S. Effect of various LED light color on the behavior and stress response of laying hens. Indian Journal of Animal Sciences. 2013. Vol. 83. P. 829-833.

22. Svobodova J., Tumova E., Popelarova E., Chodova D. Effect of light colour on egg production and egg contamination. Czech Journal of Animal Science. 2015. Vol. 60. P. 550-556. doi:10.17221/8597-CJAS

23. Yang Y., Yu Y., Pan J., Ying Y., Zhou H. A new method to manipulate broiler chicken growth and metabolism: Response to mixed LED light system. Scientific Reports. 2016. Vol. 6. № 25972. doi:10.1038/srep25972

24. Yenilmez L.F., Saber S.N., Serbester U., Celik L. Effects of monochromatic light on performance, egg quality, yolk cholesterol and blood biochemical profile of laying hens. The Journal of Animal \& Plant Sciences. 2021. Vol. 31(1) P. 46-52. doi:10.36899/JAPS.2021.1.0191

25. Zhang X., Hongqing X.U., Monan L.I., Hongmei X.U., Muqing L.I.U. Effects of different monochromatic light of LED on the growth performance of Jinmao broilers and egg laying performance of Jinmao breeders. Journal of Science and Technology in Lighting. 2017. Vol. 41. P. 143-147. doi:10.2150/JSTL.IEIJ160000592

\section{References}

1. Kavtarashvili, A.Sh. (2013). Opredelenie effektivnosti proizvodstva ptitsevodcheskoy produktsii ekspressmetodami [Determining the efficiency of poultry production by express methods]. Economics, 2(123), 6-9. [in Russian].

2. Borille, R., Garcia, R.G., Naas, I.A., Caldara, R.F., Santana, M.R. (2015). Monochromatic lightemitting diode (LED) source in layers hens during the second 
Осадча Ю. В., Сахацький Г. I.

production cycle. Revista Brasileira de Engenharia Agrícola e Ambiental, 19(9), 877881. doi:10.1590/18071929/agriambi.v19n9p877-881

3. Borille, R., Garcia, R.G., Royer, A.F.B., Santana, M.R., Colet, S., Naas, I.A., Caldara, F.R., Almeida, Paz I.C.L., Rosa, E.S., Castilho, V.A.R. (2013). The use of lightemitting diodes (LED) in commercial layer production. Brazilian Journal of Poultry Science, 15(2), 135-140. doi:10.1590/S1516635X2013000200009

4. Er, D., Wang, Z., Cao, J., Chen, Y. (2007). Effect of monochromatic light on the egg quality of laying hens. Journal of Applied Poultry Research, 16(4), 605-612. doi:10.3382/japr.2006-00096

5. Hassan, M.R., Sultana, S., Choe, H.S., Ryu, K.S. (2013). Effect of monochromatic and combined light colour on performance, blood parameters, ovarian morphology and reproductive hormones in laying hens. Italian Journal of Animal Science, 12(3), 359-364. doi:10.4081/ijas.2013.e56

6. Huber-Eicher, B., Suter, A., SpringStähli, P. (2013). Effects of colored lightemitting diode illumination on behavior and performance of laying hens. Poultry science, 92, 869-873. doi:10.3382/ps.2012-02679

7. Kim, M.J., Choi, H.C., Suh, O.S. (2010). A study of different sources and wavelengths of light on laying egg characteristics in laying hens. Korean Journal of Poultry Science, 37, 383-388. doi:10.5536/kjps.2010.37.4.383

8. Lewis, P.D., Caston, L., Leeson, S. (2007). Green light during rearing does not significantly affect the performance of egg-type pullets in the laying phase. Poultry Science, 86, 739-743. doi:10.1093/ps/86.4.739

9. Li, G., Li, B., Zhao, Y., Shi, Z., Liu, Y., Zheng, W. (2019). Layer pullet preferences for light colors of light-emitting diodes. Animal, 13(6), 1245-1251. doi: $10.1017 / \mathrm{S} 1751731118002537$

10. Li, D.Y., Wu, N., Tu, J.B., Hu, Y.D., Yang, M.Y., Yin, H.D., Chen, B.L., Xu, H.L., Yao, Y.F., Zhu, Q. (2015). Expression patterns of melatonin receptors in chicken ovarian follicles affected by monochromatic light. Genetics and Molecular Research, 14 (3), 10072-10080. doi:10.4238/2015.August.21.14
11. Li, X., Zheng, Z., Pan, J., Jiang, D., Tian, Y., Fang, L., Huang, Y. (2020). Impacts of colored light-emitting diode illumination on the growth performance and fecal microbiota in goose. Poultry science, 99(4), 1805-1812. doi:10.1016/j.psj.2019.12.034

12. Manser, C. E. (1996). Effects of lighting on the welfare of domesticpoultry: a review. Animal Welfare, 5, 341-360.

13. Min, J.K., Hossan, M.S., Nazma, A., Jae, C.N., Han, T.B., Hwan, K.K., Dong, W.K., Hyun, S.C., Hee, C.C., Ok, S.S. (2012). Effect of monochromatic light on sexual maturity, production performance and egg quality of laying hens. Avian Biology Research, 5, 69-74. doi:10.3184/175815512X13350270679453

14. Mudhar, A.S., Tabeekh, A. (2016). The effect of color light and stocking density on some enzymes and hormones of broilers and layers. Mirror of Research in Veterinary Sciences and Animals, 5(1), 25-37. doi:10.5923/j.zoology.20160602.02

15. Patel, S.J., Patel, A.S., Patel, M.D., Patel, J.H. (2016). Significance of light in poultry production: a review. Advancements in Life Sciences, 5, 1154-1160.

16. Prayitno, D.S., Phillips, C.J.C., Omed, H. (1997). The effects of color of lighting on the behavior and production of meat chickens. Poultry science, 76, 452-457. doi:10.1093/ps/76.3.452

17. Prescott, N.B., Wathes, C.M. (1999). Spectral sensitivity of domestic fowl (Gallus $g$. domesticus). British Poultry Science, 40, 332339. doi:10.1080/00071669987412

18. Rozenboim, I., Biran, I., Uni, Z., Robinzon, B., Halevy, O. (1999). The effect of monochromatic light on broiler growth and development. Poultry science, 78, 135-138. doi:10.1093/ps/78.1.135

19. Rozenboim, I., Zilberman, E., Gvaryahu, G. (1999). New monochromatic light source for laying hens. Poultry Science, 77, 1695-1698. doi:10.1093/ps/77.11.1695

20. Shi, H., Li, B., Tong, Q., Zheng, W., Zeng, D., Feng, G. (2019). Effects of LED Light Color and Intensity on Feather Pecking and Fear Responses of Layer Breeders in Natural Mating Colony Cages. Animals : an open access journal from MDPI, 9(10), 814. doi:10.3390/ani9100814 
Осадча Ю. В., Сахацький Г. І.

21. Sultana, S., Hassan, M.R., Choe, H.S., Kang, M.I., Ryu, K.S. (2013). Effect of various LED light color on the behavior and stress response of laying hens. Indian Journal of Animal Sciences, 83, 829-833.

22. Svobodova, J., Tumova, E., Popelarova, E., Chodova, D. (2015). Effect of light colour on egg production and egg contamination. Czech Journal of Animal Science, 60, 550-556. doi:10.17221/8597CJAS

23. Yang, Y., Yu, Y., Pan, J., Ying, Y., Zhou, H. (2016). A new method to manipulate broiler chicken growth and metabolism: Response to mixed LED light system. Scientific Reports, 6, 25972. doi:10.1038/srep25972
24. Yenilmez, L.F., Saber, S.N., Serbester, U., Celik, L. (2021). Effects of monochromatic light on performance, egg quality, yolk cholesterol and blood biochemical profile of laying hens. The Journal of Animal \& Plant Sciences, 31(1), 46-52. doi:10.36899/JAPS.2021.1.0191

25. Zhang, X., Hongqing, X.U., Monan, L.I., Hongmei, X.U., Muqing, L.I.U. (2017). Effects of different monochromatic light of LED on the growth performance of Jinmao broilers and egg laying performance of Jinmao breeders. Journal of Science and Technology in Lighting, 41 , 143-147. doi:10.2150/JSTL.IEIJ160000592

\section{ЭФФЕКТИВНОСТЬ ПРОИЗВОДСТВА ПИЩЕВЫХ ЯИЦ ПРИ ИСПОЛЬЗОВАНИИ ДЛЯ СОДЕРЖАНИЯ НЕСУШЕК МОНОХРОМНОГО СВЕТА С РАЗНОЙ ДЛИНОЙ СВЕТОВОЙ ВОЛНЫ Ю. В. Осадчая, Г. И. Сахацкий}

Аннотация. Исследована эффективность производства пищевых яиц при использовании для содержания кур-несушек монохромного света с разной длиной световой волны. Обнаружено, что уменьшение длины световой волны с 653 до 632 нм, то есть изменение ивета света с красного на оранжевый, не приводит к значительному снижению сохранности кур и массы их яии, однако сопровождается снижением яйценоскости, что приводит к снижению выхода яйцемассы на начальную несушку, в результате европейский коэффициент эффективности производства яии снижается на 1,0 ед. Уменьшение длинь световой волны до 603 нм, то есть до желтого ивета, приводит $к$ существенному снижению сохранности поголовья $и$ яйценоскости при повытении затрат корма на производство 1 кг яйцемассы, что приводит к снижению европейского коэффиџиента производства яии на 2,6 ед. Дальнейшее уменьшение длины волны света до 458 нм, то есть до голубого ивета, сопровождается нарастающим снижением сохранности поголовья $u$ яйщеноскости при повышении затрат корма на производство 1 кг яйщемассы, что в конечном итоге приводит к снижению европейского коэффициента эффективности производства пищевых яиц на 3,8 ед.

Ключевые слова: куры несушки, яйценоскость, яйцемасса, сохранность, живая масса, длина световой волны, ивет света 
Осадча Ю. В., Сахацький Г. І.

\title{
EFFICIENCY OF FOOD EGG PRODUCTION USED FOR KEEPING LAYERS OF MONOCHROME LIGHT WITH DIFFERENT WAVELENGTHS \\ Yu. Osadcha, G. Sakhatsky
}

\begin{abstract}
The efficiency of egg production for the use of monochrome light with different wavelengths for keeping laying hens has been studied. It was found that reducing the wavelength of light from 653 to $632 \mathrm{~nm}$, that is changing the light color from red to orange, does not lead to a significant reduction in their preservation and egg weight, but is accompanied by a decrease in egg production, resulting in reduced egg yield the European egg production rate is reduced by 1.0 units. Reducing the wavelength of light to $603 \mathrm{~nm}$, that is to yellow, already leads to a significant reduction in the preservation and egg production by increasing feed costs for the production of $1 \mathrm{~kg}$ of egg mass, which reduces the European egg production rate by 2.6 units. A further decrease in the wavelength of light to $458 \mathrm{~nm}$, that is to a blue color, is accompanied by an increasing decrease in the preservation and egg production due to increased feed costs for the production of $1 \mathrm{~kg}$ of egg mass, which ultimately reduces the European egg production rate by 3.8 units.

Key words: laying hens, egg-laying, egg mass, preservation, live weight, light wavelength, light color
\end{abstract}

